\title{
Hydrogeologic Framework of the Shallow Ground-Water System in the Cox Hall Creek Basin, Cape May County, New Jersey
}

by Pierre J. Lacombe and Otto S. Zapecza

In cooperation with the

Cape May County Board of Chosen Freeholders and the

New Jersey Department of Environmental Protection

Open-File Report 2006-1044 


\section{U.S. Department of the Interior DIRK KEMPTHORNE, Secretary \\ U.S. Geological Survey \\ P. Patrick Leahy, Acting Director}

U.S. Geological Survey, Reston, Virginia: 2006

For product and ordering information:

World Wide Web: http://www.usgs.gov/pubprod

Telephone: 1-888-ASK-USGS

For more information on the USGS--the Federal source for science about the Earth, its natural and living resources, natural hazards, and the environment:

World Wide Web: http://www.usgs.gov

Telephone: 1-888-ASK-USGS

Any use of trade, product, or firm names is for descriptive purposes only and does not imply endorsement by the U.S. Government.

Although this report is in the public domain, permission must be secured from the individual copyright owners to reproduce any copyrighted materials contained within this report. 


\section{Contents}

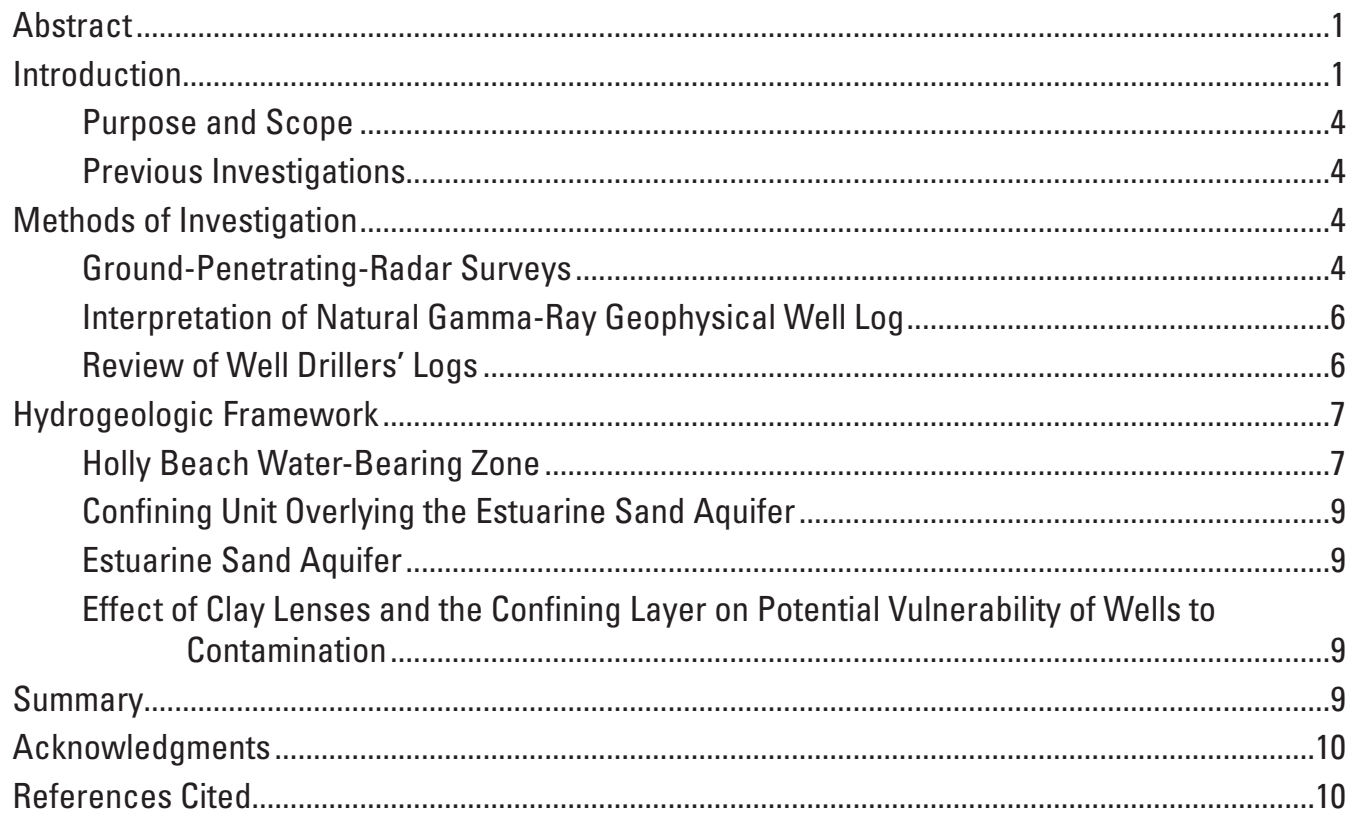

\section{Figures}

1-3. Maps showing-

1. Location of Cox Hall Creek Basin, Lower Township, Cape May County, New Jersey.

2. Cox Hall Creek Basin, Cox Hall Creek, Mickels Run, and the Cox Hall Creek tide gate, Lower Township, Cape May County, New Jersey.

3. Ground-penetrating-radar traverses, lines of hydrogeologic section, and 28 privately owned domestic wells in the Cox Hall Creek Basin, Lower Township, Cape May County, New Jersey.

4. Photograph showing a ground-penetrating-radar (GPR) unit.........................................6

5. Section A-A' showing the hydrogeologic framework along Clubhouse Road and Bay Drive, location and screened interval of selected wells, and the natural gamma-ray log for well 9-210 in the Cox Hall Creek Basin, Lower Township, Cape May County, New Jersey

6. Section B-B' showing the hydrogeologic framework along Avalon Road, location and screened interval of selected wells, and the natural gamma-ray log for well 9-210 in the Cox Hall Creek Basin, Lower Township, Cape May County, New Jersey......8 


\section{Table}

1. New Jersey Department of Environmental Protection (NJDEP) well permit numbers for 28 selected privately owned domestic wells in the Cox Hall Creek area, Cape May County, New Jersey.

\section{CONVERSION FACTORS AND VERTICAL DATUMS}

\begin{tabular}{lll}
\hline Multiply & \multicolumn{1}{c}{ By } & To obtain \\
\hline inch (in.) & \multicolumn{1}{c}{ Length } & \\
foot (ft) & 2.54 & centimeter \\
mile (mi) & 0.3 & meter \\
\hline \multicolumn{2}{c}{ Area } & kilometer \\
\hline square mile $\left(\mathrm{mi}^{2}\right)$ & 1.61 & square kilometer \\
\hline megahertz $(\mathrm{MHz})$ & $2.59 \quad$ Frequency & \\
\hline
\end{tabular}

Mean sea level, the vertical datum used for the purposes of this report, is a tidal datum that pertains to local mean sea level; it is not a fixed datum and is not equivalent to the National Geodetic Vertical Datum of 1929 (NGVD 29). 


\title{
Hydrogeologic Framework of the Shallow Ground-Water System in the Cox Hall Creek Basin, Cape May County, New Jersey
}

\author{
by Pierre J. Lacombe and Otto S. Zapecza
}

\section{Abstract}

Cape May County is investigating the feasibility of restoring the lowermost reach of Cox Hall Creek to its former state as a tidal saltwater wetland; however, the potential for contamination of the shallow ground-water system, which provides water to hundreds of nearby privately owned domestic wells, with saltwater from the restored wetland is of particular concern. To evaluate the potential effectiveness and risks of restoring the saltwater wetlands, the County needs information about the hydrogeologic framework in the area, and about the potential vulnerability of the domestic wells to contamination.

The shallow ground-water system in the Cox Hall Creek area consists of unconsolidated Holocene and Pleistocene deposits. The Holly Beach water-bearing zone, the unconfined (water-table) aquifer, is about 35 feet thick and contains a 2- to 4-foot-thick clay lens about 10 feet below land surface; a lower, more discontinuous clay lens about 30 to 35 feet below land surface ranges up to 5 feet in thickness. A 75-foot-thick confining unit separates the Holly Beach water-bearing zone from the underlying estuarine sand aquifer.

The clay lenses in the Holly Beach water-bearing zone likely retard the movement of contaminants from septic tanks, lawns, and other surficial sources, protecting wells that tap the lower, sandy part of the aquifer. The clay lenses also may protect these wells from salty surface water if withdrawals from the Holly Beach water-bearing zone are not increased substantially. Deeper wells that tap the estuarine sand aquifer are more effectively protected from saltwater from surface sources because of the presence of the overlying confining unit.

\section{Introduction}

Cox Hall Creek Basin, a small watershed in the southwestern part of Lower Township in Cape May County, New Jersey (fig. 1), encompasses about $3.36 \mathrm{mi}^{2}$ (fig. 2) and is relatively flat, with land-surface elevations ranging from -2 to $21 \mathrm{ft}$. The primary streams in the basin, Cox Hall Creek and its tributary, Mickels Run, flow west and discharge to the Delaware Bay. Before about 1930, wetlands at the confluence of Cox Hall Creek and Mickels Run were affected by tides and, therefore, were salty. The saltwater wetlands flooded twice daily with each high tide that flowed in from the Delaware Bay. Construction of a dam and tide gate (an opening through which water flows freely in one direction but which closes automatically and prevents the water from flowing in the other direction) at the mouth of Cox Hall Creek effectively restricted the tidal movement of saltwater to this estuarine basin, resulting in the creation of a complex of freshwater wetlands. The quality of water in these wetlands has been altered by contaminants from point and nonpoint sources, including discharge from a sewage-treatment plant into Cox Hall Creek during 1969-90; 14 stormwater outfalls; septic systems; and runoff from residential, commercial, and agricultural areas.

As a result of three interventions, the former saltwater wetland has become a freshwater marsh that contains fecal coliform bacteria at concentrations that can exceed the New Jersey maximum contaminant level. The interventions are (1) construction of the dam, which prevented tidal flushing; (2) intensive residential development in the village of Town Bank beginning in the 1950s, which increased the volume of, and contributed nonpoint-source contaminants to, stormwater runoff; and (3) the discharge of processed wastewater from the sewage-treatment plant for more than 20 years. On many occasions, excessive concentrations of fecal coliform bacteria have caused beaches near the mouth of Cox Hall Creek to be declared unsafe for swimming. Phragmites, a non-native species of common freshwater reedgrass, has choked wetlands channels, caused drainage problems, and become a fire hazard to adjacent residences.

To improve drainage and the quality of both surface water and ecological habitats, and to reduce fire potential, Cape May County is investigating the potential of restoring the lower reach of Cox Hall Creek to its former state as a tidal saltwater 


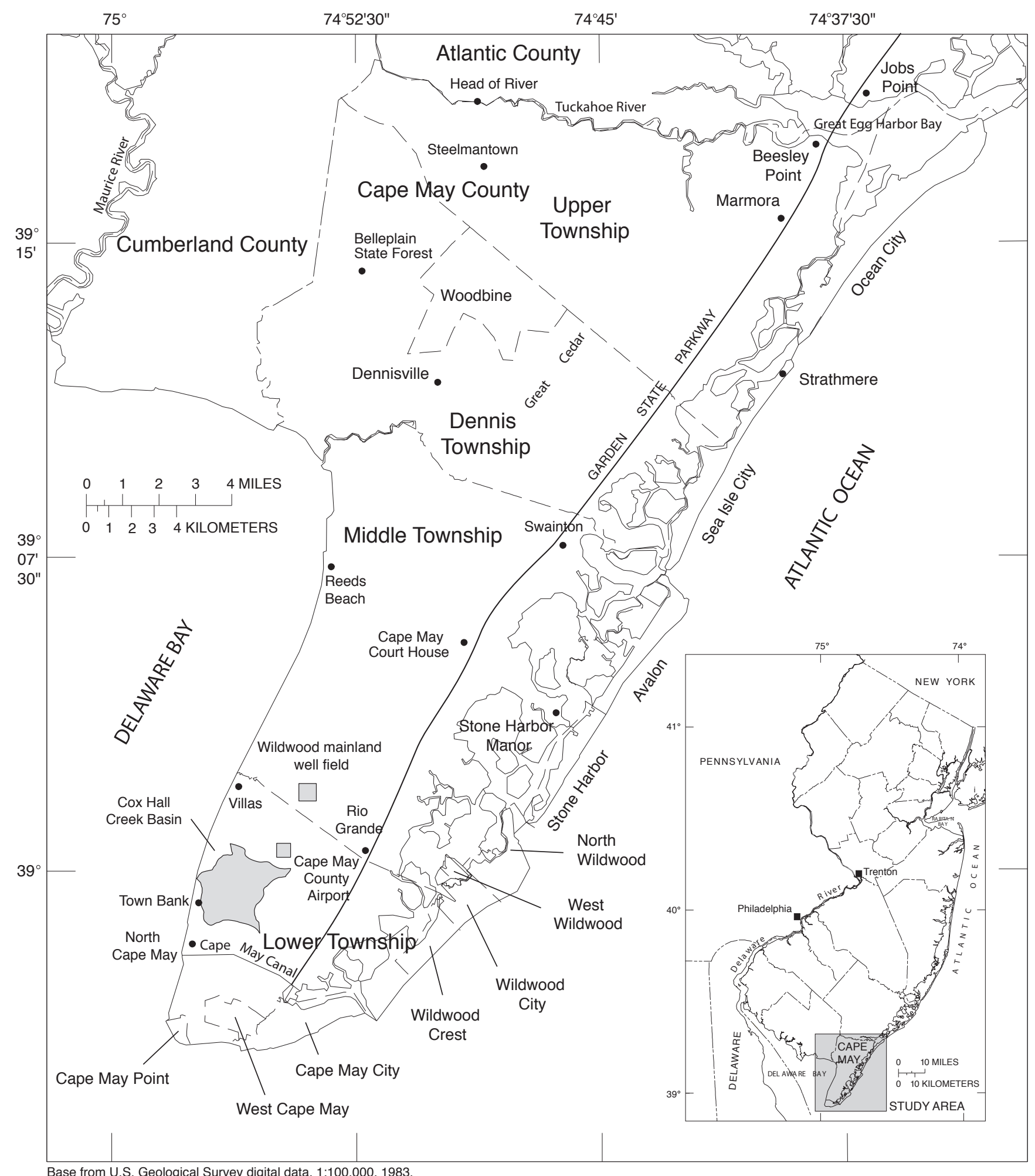

Base from U.S. Geological Survey digital data, 1:100,000, 1983.

Universal Transverse Mercator Projection, Zone 18

Figure 1. Location of Cox Hall Creek Basin, Lower Township, Cape May County, New Jersey. 


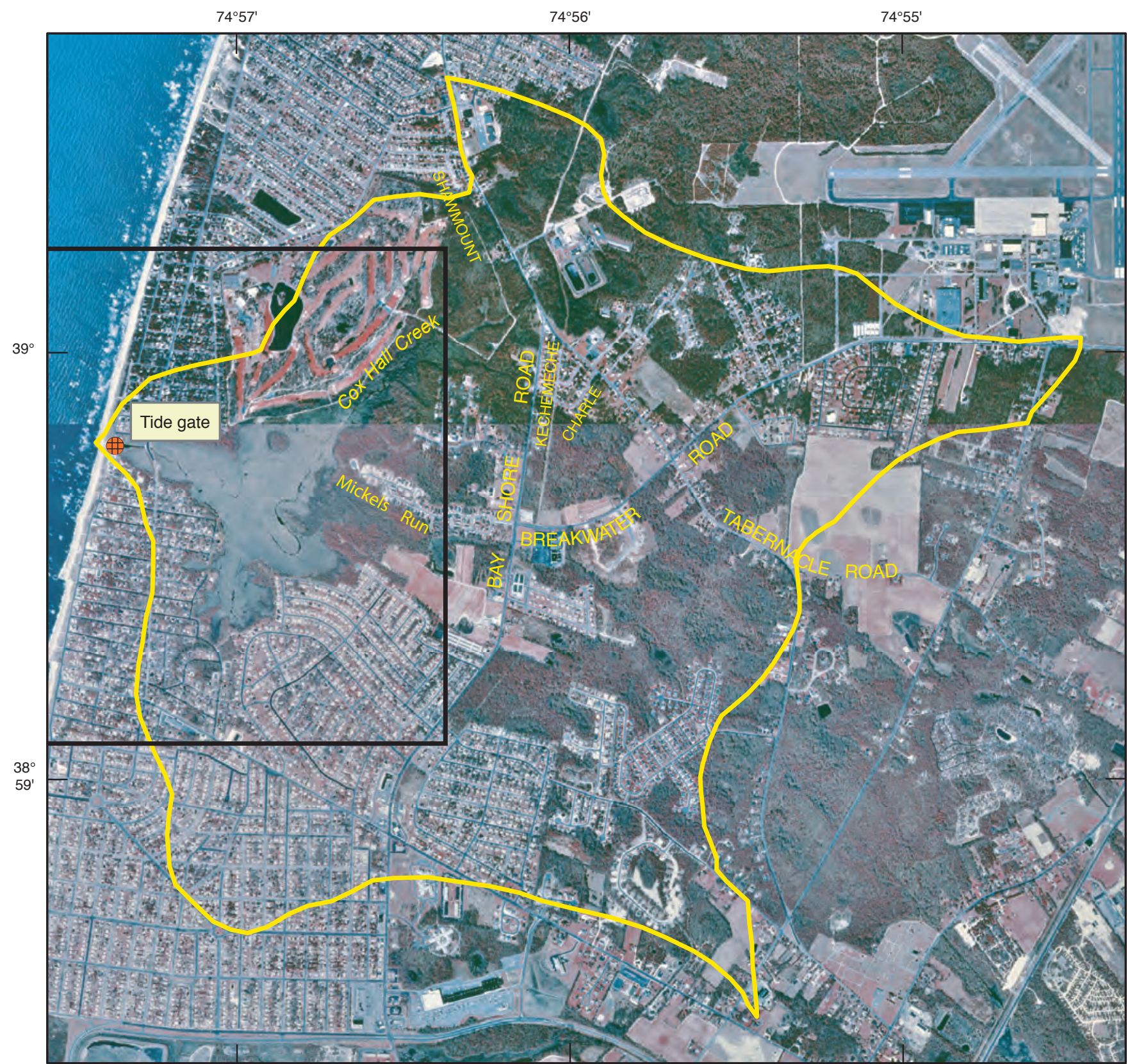

Base from U.S. Geological Survey

digital infrared orthophoto quads, 1995

\section{EXPLANATION}

Boundary of Cox Hall Creek Basin

Boundary of area shown in figure 3

Figure 2. Cox Hall Creek Basin, Cox Hall Creek, Mickels Run, and the Cox Hall Creek tide gate, Lower Township, Cape May County, New Jersey. 
wetland. However, the potential for contamination of the shallow ground-water system, the source of water to hundreds of nearby privately owned domestic wells, with saltwater from the restored wetland is of particular concern.

To evaluate the potential effectiveness and risks of restoring the saltwater wetlands, the County needs information about the hydrogeologic framework in the area, and about the potential vulnerability of the domestic wells to contamination from the surface. To address these information needs, the U.S. Geological Survey (USGS), in cooperation with the Cape May County Board of Chosen Freeholders and the N.J. Department of Environmental Protection (NJDEP), conducted a study in fall 2002 to characterize the framework of the shallow groundwater system in the wetlands area of the Cox Hall Creek Basin. The characterization was made on the basis of interpretations of ground-penetrating-radar (GPR) surveys and a borehole geophysical log, and analyses of available lithologic logs of sediments encountered during well drilling in conjunction with a previously published interpretation of the regional hydrogeology. Hydrogeologic sections developed from these data were combined with available well-construction information for the domestic wells to assess the wells' potential vulnerability to contamination from the restored saltwater wetlands. The geophysical methods used and the types of data collected can be applied to the study of the many wetlands adjacent to the Delaware Bay and other coastal areas that are similarly protected from tides.

\section{Purpose and Scope}

This report presents the results of an investigation of the hydrogeologic framework of the shallow ground-water system in the vicinity of the Cox Hall Creek wetlands adjacent to the village of Town Bank in Lower Township, Cape May County, New Jersey. The use of ground-penetrating radar and borehole geophysical methods in conjunction with well drillers' logs to delineate the framework is described. Hydrogeologic sections developed from the geophysical and lithologic data are combined with records of well locations and screen placement to characterize the effect of confining layers on the potential vulnerability of wells in the Cox Hall Creek area to contamination from the surface.

\section{Previous Investigations}

Comprehensive regional studies of the hydrogeologic framework and ground-water resources of Cape May County, New Jersey, by the USGS include those by Gill (1962) and Lacombe and Carleton (2002). Spitz $(1996,1998)$ investigated the hydrologic feasibility of water-supply-development alternatives in Cape May County and simulated ground-water flow and saltwater encroachment in the shallow aquifer system. Surficial geologic maps of southern New Jersey by Newell and others (2000) include a description of surficial sediments in the Cox Hall Creek area.

\section{Methods of Investigation}

Ground-penetrating-radar (GPR) surveys were conducted along four traverses adjacent to the Cox Hall Creek wetlands in the village of Town Bank (fig. 3). A natural gamma-ray log was run in USGS observation well 9-210 on the west side of the wetland area, and well-construction records, including well drillers' logs, for the 28 privately owned domestic wells for which such records were available, were reviewed.

\section{Ground-Penetrating-Radar Surveys}

A GPR survey is a method of determining shallow subsurface lithology and hydrogeology along continuous transects without drilling wells or excavating trenches. A radar signal is emitted from a transmitting antenna and the reflected signal is received at a receiving antenna. The radar signals are reflected by subsurface features such as the water table and sand and gravel strata, and are attenuated by clay strata and saltwater. The data from the radar signals are recorded as digital files and on paper strip charts as hundreds of wiggle traces. The data are interpreted by comparing them with available information on known geologic and hydrologic features and characteristics, information from well logs, and water levels.

On October 8, 2002, the USGS conducted a GPR survey using a Mala Geoscience GPR system. This system consists of 100-megahertz (MHz) unshielded transmitting and receiving antennas, electronics, a personal (laptop) computer, and rechargeable batteries (fig. 4). The transmitting antenna was fixed at a 1-meter separation from the receiving antenna, and all associated electronics and batteries were attached to the antenna network. A field person carried the antenna network along a designated traverse, about 2 in. above land surface. Data were collected at a normal walking pace of about 200 to $250 \mathrm{ft} / \mathrm{min}$. Signals were transferred through a cable to the data-processing electronics and recording equipment in a backpack and a personal computer in a frontpack carried by a second person. The settings for the GPR system were maintained at the manufacturer's default settings. Field personnel who carried the data-processing electronics and personal computer noted the locations of major features, such as road intersections, forest and field edges, wells, and other obvious physical features, along each traverse.

GPR data were collected along public roads along the west side of the lower Cox Hall Creek wetlands, including part or all of the following residential streets: Shore Drive, Mallow Road, Clubhouse Road, Fernwood Road, Norcross Road, Brookdale Road, Lawnside Road, Delair Road, Oxford Road, Race Track Road, and a dirt utility path on the west side of the Cox Hall Creek wetlands, as well as across the Ponder Lodge golf course north of the Cox Hall Creek wetlands (fig. 3). GPR data were used to determine the lateral continuity of lithologic units indicated on drillers' logs of wells in the area. Particular attention was given to the depths at which radar signals were attenuated by clay layers in the subsurface. The GPR data 


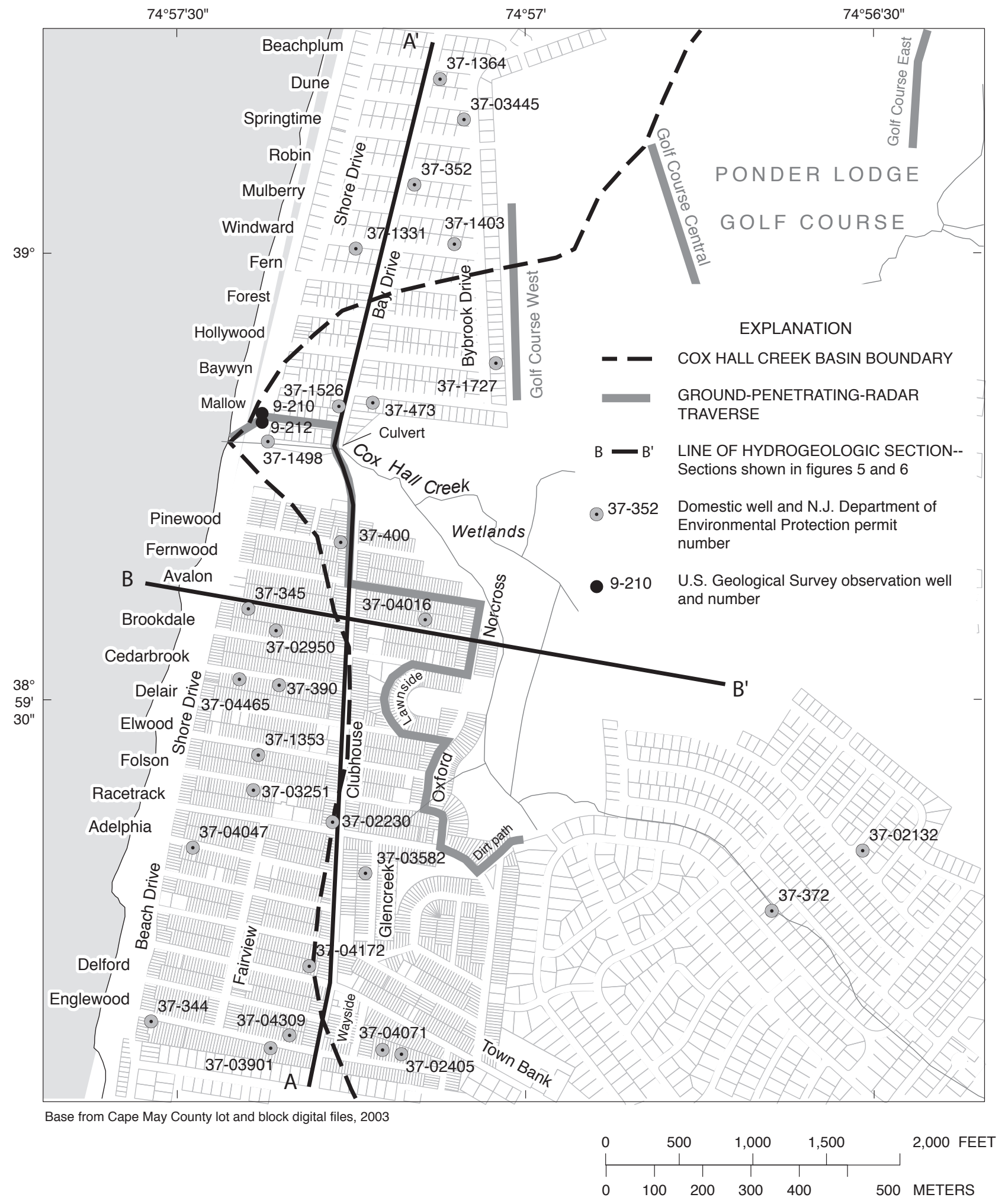

Figure 3. Ground-penetrating-radar traverses, lines of hydrogeologic section, and 28 privately owned domestic wells in the Cox Hall Creek Basin, Lower Township, Cape May County, New Jersey. 


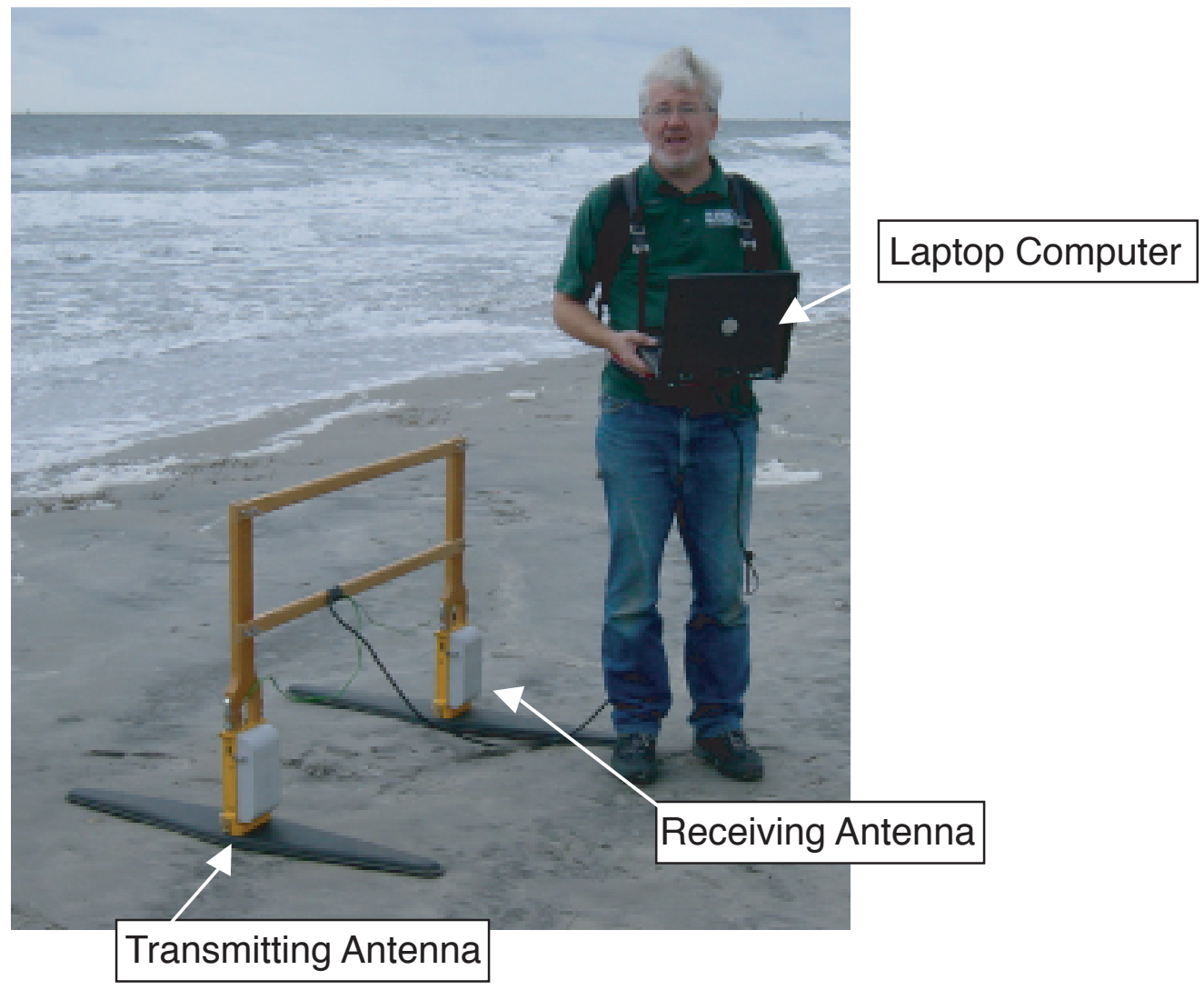

Figure 4. Ground-penetrating-radar (GPR) unit. (Transmitting and receiving antennas are the two black units lying on the beach. The gray boxes on top of the antennas are battery packs. The wood rack holds the GPR antennas a specified distance apart. A personal (laptop) computer is carried on the front of the operator and a small electronic box is carried on the back of the operator. Typically, a second field person carries the antenna unit about 2 inches above land surface.)

were enhanced with lithologic data from the natural gammaray log of well 9-210, near the mouth of Cox Hall Creek, and drillers' logs for 28 privately owned domestic wells within $600 \mathrm{ft}$ of the GPR traverses (fig. 3). These data were used to prepare hydrogeologic sections A-A' (south to north; fig. 5) and B-B' (west to east; fig. 6) through the residential community west of the Cox Hall Creek wetlands. These sections also show the vertical profiles of the privately owned domestic wells for which hydrogeologic data were available.

\section{Interpretation of Natural Gamma-Ray Geophysical Well Log}

A natural gamma-ray geophysical log was made for USGS observation well 9-210 (fig. 3). Data were recorded using a Mt. Sopris MGXII geophysical logger. Data were collected at a rate of $20 \mathrm{ft} / \mathrm{min}$ and are stored in the USGS GEOLOG database at the USGS New Jersey Water Science Center in West Trenton, New Jersey. The vertical or y-axis on the log represents depth below land surface in feet. The horizontal or $\mathrm{x}$-axis on the log represents the relative natural gamma-ray emissions in counts per second (see trace of log in figures 5 and 6). Strata with low natural gamma-ray values, such as sand and gravel, are interpreted as water-bearing units. Strata with high natural gamma-ray values are interpreted as clay or confining units.

\section{Review of Well Drillers' Logs}

In New Jersey, State-licensed well drillers must file a well record with NJDEP upon completion of a well. On each well record, the driller must indicate the property where the well is located, the purpose of the well, well-construction information, the depth of the interval that is open to the aquifer, the yield, the results of any hydraulic tests that were conducted, the pumping equipment that was installed, and the lithology of the strata that were penetrated while the borehole was being drilled. Each well record is stored on microfilm and in a computer database at the NJDEP Office of Well Records in Trenton, New Jersey. Well records for privately owned 


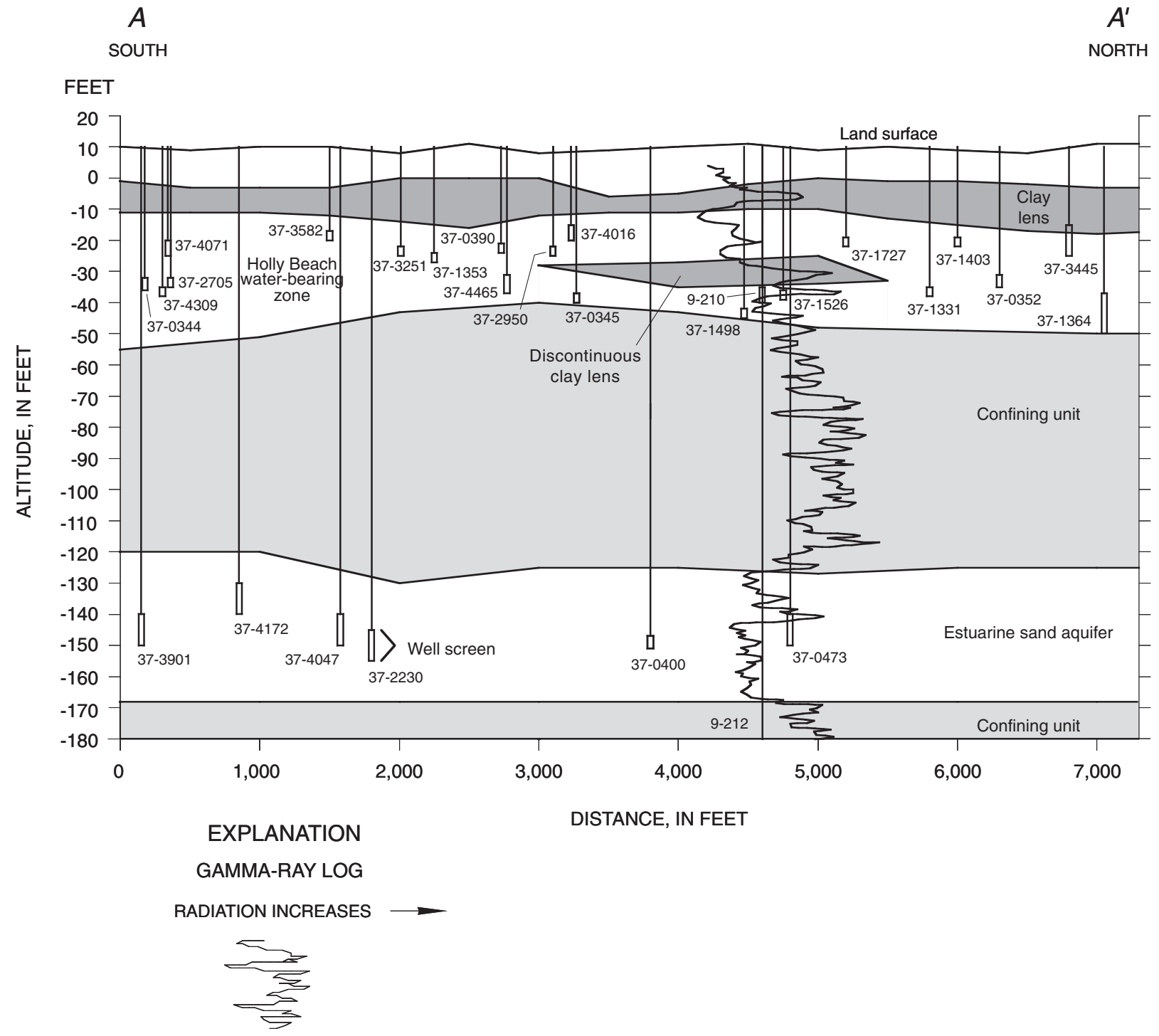

Figure 5. Section A-A' showing the hydrogeologic framework along Clubhouse Road and Bay Drive, location and screened interval of selected wells, and the natural gamma-ray log for well 9-210 in the Cox Hall Creek Basin, Lower Township, Cape May County, New Jersey. (Line of section is shown in figure 3. Datum is mean sea level.)

domestic wells used in this study are identified by their respective NJDEP well permit numbers (fig. 3 and table 1).

\section{Hydrogeologic Framework}

The descriptions of hydrogeologic units in this report are based on the regional hydrostratigraphic framework of Cape May County delineated by Lacombe and Carleton (2002). The hydrogeologic framework of the study area was characterized by combining this information with the interpretation of data from the GPR survey, natural gamma-ray logging, well drillers' logs, and well-construction records collected for this study. The shallow ground-water system in the Cox Hall Creek area consists of (from the land surface downward): unconsolidated Holocene and Pleistocene deposits that make up the unconfined Holly Beach water-bearing zone, a confining unit overlying the estuarine sand aquifer, and the estuarine sand aquifer itself.

\section{Holly Beach Water-Bearing Zone}

The Holly Beach water-bearing zone is the uppermost (unconfined) aquifer in Cape May County. In the Cox Hall Creek area, the aquifer generally consists of the upper part of the Cape May Formation and is composed predominantly of gravel interbedded with coarse- to fine-grained sand, although silt, clay, and organic muck can predominate in wetland areas. 


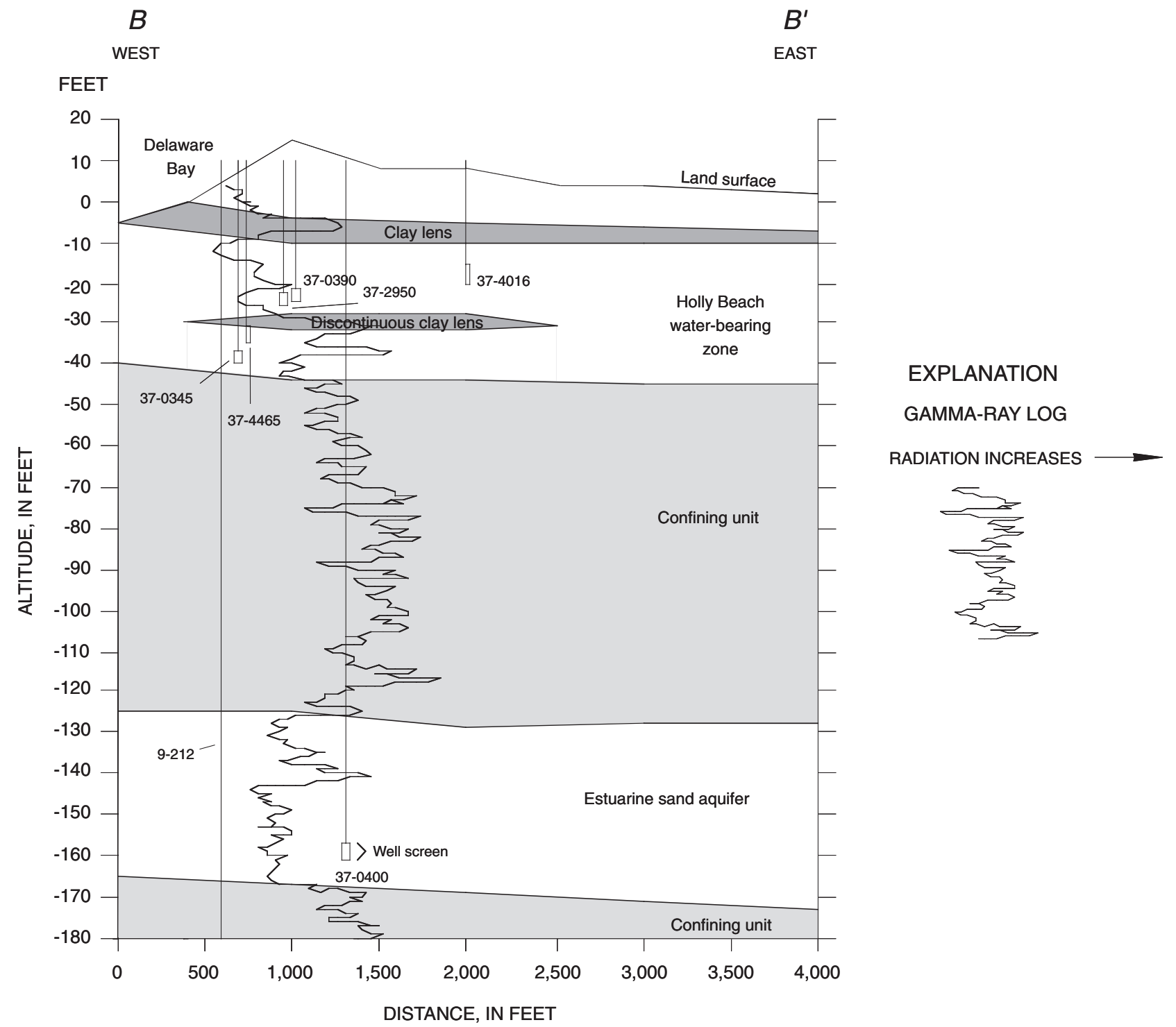

Figure 6. Section B-B' showing the hydrogeologic framework along Avalon Road, location and screened interval of selected wells, and the natural gamma-ray log for well 9-210 in the Cox Hall Creek Basin, Lower Township, Cape May County, New Jersey. (Line of section is shown in figure 3. Datum is mean sea level.)

Clay and silt lenses within the Holly Beach water-bearing zone can confine ground water locally. The aquifer contains freshwater in interior Cape May County, freshwater and saltwater beneath the saltwater wetlands and barrier islands, and saltwater beneath the Atlantic Ocean and the Delaware Bay.

In the Cox Hall Creek area, the water table is at the land surface in the wetlands. Records for wells installed from the mid-1980s to the mid-1990s show that static water levels at the time of well completion generally were less than $10 \mathrm{ft}$ below land surface in residential areas of Town Bank. This information is consistent with the water-level altitudes in 1991 reported by Lacombe and Carleton (2002, fig. 35) and with results of the GPR surveys conducted as part of this study.
According to Lacombe and Carleton (2002, fig. 14), the altitude of the base of the Holly Beach water-bearing zone in the Cox Hall Creek area is about $50 \mathrm{ft}$ below mean sea level. Hydrogeologic sections A-A' and B-B' (figs. 5 and 6, respectively) show that the base of the aquifer ranges from about -40 to $-55 \mathrm{ft}$ in the area, and that the aquifer is about $50 \mathrm{ft}$ thick. Results of the GPR surveys indicate the presence of two clay lenses within the Holly Beach water-bearing zone in the study area. An upper clay lens about 2 to $4 \mathrm{ft}$ thick underlies most of the area, and a lower, more discontinuous clay lens about 30 to $35 \mathrm{ft}$ below land surface is up to $5 \mathrm{ft}$ thick. The top of the regional confining unit that underlies the Holly Beach water- 
Table 1. New Jersey Department of Environmental Protection (NJDEP) well permit numbers for 28 selected privately owned domestic wells in the Cox Hall Creek area, Cape May County, New Jersey.

\begin{tabular}{ll}
\hline Well permit number & Well permit number \\
\hline $37-1364$ & $37-1353$ \\
$37-03445$ & $37-03251$ \\
$37-352$ & $37-02230$ \\
$37-01331$ & $37-03582$ \\
$37-1403$ & $37-04047$ \\
$37-1727$ & $37-04172$ \\
$37-473$ & $37-03901$ \\
$37-1526$ & $37-04309$ \\
$37-1498$ & $37-04071$ \\
$37-400$ & $37-02405$ \\
$37-345$ & $37-344$ \\
$37-04016$ & $37-372$ \\
$37-02950$ & $37-02132$ \\
$37-04465$ & \\
$37-390$ &
\end{tabular}

bearing zone generally was the maximum depth of penetration of the ground-penetrating radar.

\section{Confining Unit Overlying the Estuarine Sand Aquifer}

The confining unit that overlies the estuarine sand aquifer is composed predominantly of fine-grained clay and silt. Lacombe and Carleton (2002, fig. 15) show that this confining unit generally is more than $75 \mathrm{ft}$ thick in the Cox Hall Creek area. This information is consistent with the geophysical log and drillers' logs collected for this study (figs. 5 and 6). The confining unit is laterally continuous throughout most of the peninsular part of Cape May County.

\section{Estuarine Sand Aquifer}

The estuarine sand aquifer is the shallowest confined aquifer in the southern part of Cape May County. The extent of the aquifer is defined by the extent of the confining unit that overlies it. The aquifer consists of gravel and coarse- to fine-grained sand of the lower part of the Cape May Formation and the upper part of the Cohansey Formation. According to Lacombe and Carleton (2002, figs. 16 and 17), the top of the aquifer is approximately $120 \mathrm{ft}$ below mean sea level and the aquifer is about $50 \mathrm{ft}$ thick in the Cox Hall Creek area. This information is consistent with altitude and thickness data for the estuarine sand aquifer based on the geophysical log and drillers' logs collected for this study.

\section{Effect of Clay Lenses and the Confining Layer on Potential Vulnerability of Wells to Contamination}

Sections A-A' (fig. 5) and B-B' (fig. 6) show the locations and screened intervals of 28 privately owned domestic wells in the Cox Hall Creek area determined from well-construction data recorded on drillers' well records available for this study. Most of the shallow wells are completed in the lower, sandy part of the Holly Beach water-bearing zone adjacent to the Cox Hall Creek wetlands.

The clay lenses in the Holly Beach water-bearing zone likely slow the movement of contaminants from septic tanks, lawns, and other surficial sources of contamination, mitigating their effect on the quality of water in the domestic wells that tap the lower part of the aquifer. By retarding the flow of ground water, the clay lenses maximize the time available for biodegradation and adsorption of contaminants to occur. The clay lenses also may protect these wells from salty surface water if withdrawals from the Holly Beach water-bearing zone are maintained at or near current levels. If a well with a continuous screen were installed through the upper, more continuous clay lens in the Holly Beach water-bearing zone, and if the well were near the newly formed saltwater wetland or the Delaware Bay, then that well could become contaminated with saltwater, and possibly anthropogenic contaminants as well. In addition, if new wells were installed in the Holly Beach water-bearing zone west of the Cox Hall Creek wetlands and, consequently, ground-water withdrawals were increased substantially, water in wells near the saltwater wetlands and the Delaware Bay could become salty or contaminated. Deeper wells that draw water from the confined estuarine sand aquifer are more effectively protected from saltwater and other contaminants present at the surface because of the presence of the overlying regional confining unit.

\section{Summary}

Residential development in the Cox Hall Creek Basin, Lower Township, Cape May County, New Jersey, and construction of a dam and tide gate at the mouth of Cox Hall Creek have caused the formerly tidally influenced saltwater wetlands in the basin to become fresh, and have resulted in increased flooding, degraded water quality, and an increased risk of fire. Plans to restore the lower reach of Cox Hall Creek to its former state as a tidal saltwater wetland have raised concerns over the potential for contamination of the shallow ground-water system with saltwater from the surface. The shallow ground-water system in the basin is the source of water to hundreds of privately owned domestic wells.

To address the above concerns, the U.S. Geological Survey, in cooperation with the Cape May County Board of Chosen Freeholders and the N.J. Department of Environmental Protection, conducted a study in fall 2002 to characterize the 
hydrogeologic framework of the shallow ground-water system in the wetlands area of the basin through the interpretation of ground-penetrating-radar surveys, a borehole geophysical log, and available lithologic (drillers') logs in conjunction with a previously published interpretation of the regional hydrogeology. Hydrogeologic sections developed from these data were combined with available well-construction information for the domestic wells to assess the wells' potential vulnerability to contamination from restored saltwater wetlands.

The shallow ground-water system in the Cox Hall Creek area consists of unconsolidated Holocene and Pleistocene deposits. The Holly Beach water-bearing zone, the unconfined aquifer, is about $35 \mathrm{ft}$ thick and contains a 2- to 4-ft-thick clay lens about $10 \mathrm{ft}$ below land surface, and a lower, more discontinuous clay lens about $5 \mathrm{ft}$ thick. A 75-ft-thick confining unit separates the Holly Beach water-bearing zone from the underlying estuarine sand aquifer.

The clay lenses in the Holly Beach water-bearing zone likely retard the movement of contaminants from the surface and protect wells that are screened in the lower, sandy part of the aquifer. The clay lenses also may protect these wells from saltwater from the restored wetlands provided that withdrawals from the Holly Beach water-bearing zone are not increased substantially. Shallow wells with continuous screens installed through the clay lenses near the restored saltwater wetlands or the Delaware Bay potentially would be vulnerable to contamination. Wells that tap the estuarine sand aquifer are more effectively protected from saltwater from surface sources because of the presence of the overlying confining unit.

\section{Acknowledgments}

The author thanks Peter Joesten of the USGS for his assistance in the field during data collection. In addition, $\mathrm{Mr}$. Joesten provided a technical review of the data presentation and interpretation. The author also thanks Brian O'Connor and John Vona of the Cape May County Planning Department for assistance in operating the GPR instruments and recording location information in the field.

\section{References Cited}

Gill, H.E., 1962, Ground-water resources of Cape May County, N.J.--Saltwater invasion of principal aquifers: New Jersey Department of Conservation and Economic Development Special Report 18, 171 p.
Lacombe, P.J., and Carleton, G.B., 2002, Hydrogeologic framework, availability of water supplies, and saltwater intrusion, Cape May County, New Jersey: U.S. Geological Survey Water-Resources Investigations Report 01-4246, $151 \mathrm{p}$.

Newell, W.L., Powars, D.S., Owens, J.P., Stanford, S.D., and Stone, B.D., 2000, Surficial geologic map of central and southern New Jersey: U.S. Geological Survey Miscellaneous Investigations Series Map I-2540-D, 3 pl. and pamphlet.

Spitz, F.J., 1996, Hydrologic feasibility of water-supply-development alternatives in Cape May County, New Jersey: U.S. Geological Survey Water-Resources Investigations Report 96-4041, 42 p.

Spitz, F.J., 1998, Analysis of ground-water flow and saltwater encroachment in the shallow aquifer system of Cape May County, New Jersey: U.S. Geological Survey Water-Supply Paper 2490, 51 p. 